\title{
ON CERTAIN MALAYSIAN SPECIES OF MELIOSMA BLUME ${ }^{1}$
}

\author{
E. D. Merrill and L. M. Perry
}

In STUDying the assembled Meliosma material (excluding the Chinese collections) in the herbarium of the Arnold Arboretum we note some significant extensions of range, and include also the description of three hitherto apparently undescribed species. These data are embodied in the present paper.

Meliosma Bartlettii nom. nov.

Meliosma trichocarpa Merr. Pap. Michigan Acad. Sci. 24(1): 80. 1938 (1939), non Handel-Mazzetti, 1934.

A new name is needed for this Sumatran species, which was based on a series of specimens secured by Professor H. H. Bartlett's native collector Rahmat. Handel-Mazzetti used the name for a Chinese species in 1934; hence, this necessary change.

Meliosma pedicellata Koord. \& Val. Meded. Lands Plant. 61: 134. 1903 (Bijdr. Boomsoort. Java 9:134), Atlas Baumart. Java 2: f. 379. 1914.

British North Borneo: Mount Kinabalu, Upper Kinataki River, Clemens 31993, February 22, 1933, at about $2100 \mathrm{~m}$. alt.; Penataran River, Clemens 33631, June 21, 1933, at about 2700 m. alt.; Colombon River, Clemens 33710, June 27, 1933, at about 1700 m. alt.

These collections differ from the original description and plate of Meliosma pedicellata Koord. \& Val. only in the somewhat larger leaves (9-18 cm. long, 3.5-8 cm. broad).

Meliosma ferruginea Blume, Cat. Gew. Buitenz. 32. 1823; Nees, Bot. Zeit. 8(1): 106. 1825; Blume, Rumphia 3: 200. 1847; Miq. Fl. Ind. Bat. 1(2): 616. 1859, Fl. Arch. Ind. 74. 1871; Koord. \& Val. Meded. Lands Plant. 61: 121. 1903 (Bijdr. Boomsoort. Java 9: 121), Atlas Baumart. Java 2: f. 375. 1914.

Millingtonia ferruginea Schult. Syst. Veg. Mant. 1, Add. 2: 250. 1827.

Northeastern New Guinea: Morobe District, Clemens 2168, March 26, 1936, at about 600 m. alt.; Wareo, Clemens 1578, January 10,1936 , at about $600 \mathrm{~m}$. alt.

${ }^{1}$ Botanical Results of the Richard Archbold Expeditions. 
These specimens show only leaves, buds and immature fruit. Although with flowering material for comparison, they may prove to represent a new species, they compare most favorably with the Bornean and Javan specimens of Meliosma ferruginea Blume as to the indumentum, and the size and outline of the leaflets.

Meliosma sumatrana (Jack) Walpers, Annales 1:135. 1848; Miquel, Fl. Ind. Bat. 1(2) : 617. 1859; Hooker f. Fl. Brit. Ind. 2: 6. 1876.

Millingtonia sumatrana Jack, Malay. Miscel. 2(7) : 30. 1822.

Meliosma Diepenhorstii Val. Ic. Bog. 2: t. 150. 1904.

British North Borneo: Mount Kinabalu, Penibukan, Clemens $30321,30516,31699=31844,40738,50187$.

With some hesitation we assign these collections to this species. All specimens except the last show fruit; in no. 50187 the inflorescence has not reached anthesis. The fruits compare favorably with specimens of this species from Sumatra; usually, however, the base of the petiolule is more enlarged in the Bornean material. Although we have no authentic material for comparison, on account of the differences in the shape and the size of the inner petals of the two species we have omitted Meliosma nitida Blume from the synonymy of this one. In this, $M$. sumatrana (Jack) Walp., the inner petals are distinctly acute and project above the filaments. In $M$. nitida Blume they are described as shorter than the filaments and repand-crenulate at the apex.

Meliosma philippinensis sp. nov.

Meliosma sumatrana sensu Merr. Enum. Philip. Fl. Pl. 2: 518. 1923, non Walp.

Ramuli teretes, glabri; foliis impari-pinnatis, alternis, glabris, vel in rachi, costa nervisque parce puberulis, plerumque 3-4-jugis; rachi 15-23 $\mathrm{cm}$. longa; petiolulis $\pm 1 \mathrm{~cm}$. longis; foliolis suboppositis, lanceolatooblongis ad ellipticis, acuminatis, basi in petiolum angustatis, integris vel parce dentatis, chartaceo-coriaceis, reticulatis, subtus venis prominentibus; inflorescentiis circiter $30 \mathrm{~cm}$. longis, rachi ramulisque pubescentibus; floribus glabris; sepalis late rotundis; petalis exterioribus obovatoorbicularibus, circiter $1.5 \mathrm{~mm}$. longis, $2 \mathrm{~mm}$. latis, interioribus vix 1.5 $\mathrm{mm}$. longis, filamentis paullum brevioribus, cuneatis, apice retusis vel erosis; ovario glaberrimo, disco 5-denticulato cincto; drupis subglobosis vel obovoideis, basi laterali gibberosis; putamine oblique globoso, \pm $1 \mathrm{~cm}$. longo, vix $1 \mathrm{~cm}$. lato, osseo, dorso costato.

Philippine Islands: Mindanao, Surigao, Wenzel 2534 (type), 2945, 3331, Mallonga (For. Bur. 27000); Zamboanga District, Ramos \& 
Edaño (Bur. Sci. 37368); Lanao District, Alvarez (For. Bur. 25173); Bukidnon Subprovince, Edaño (Bur. Sci. 39054, 39101); Mount Apo, Clemens (Bur. Sci. 15599), Elmer 10531, 11178, 13297, 13771.

This species, previously included in Meliosma sumatrana (Jack) Walp., differs from the latter in having shorter, truncate or erose, inner petals and considerably smaller fruits (scarcely half as large as in the Sumatran material). Meliosma philippinensis is more like $M$. nitida Blume, of which we have neither flowers nor fruit for comparison. The description of the latter, however, indicates ellipsoid fruits twice as large as in the Philippine form.

\section{Meliosma humilis sp. nov.}

Arbor parva; ramulis subteretibus ad apicem \pm dense ferrugineohirsutis; foliis impari-pinnatis, alternis, vulgo 4-5-jugis; rachi $20-30 \mathrm{~cm}$. longa, initio hirsuta, demum glabrata; petiolulis $\pm 1 \mathrm{~cm}$. longis, \pm hirsutis; foliolis chartaceo-coriaceis, suboppositis, patentibus, in specimine typica $\pm 9 \mathrm{~cm}$. longis, circiter $3.5 \mathrm{~cm}$. latis, in ceteris usque ad $15 \mathrm{~cm}$. longis, $6 \mathrm{~cm}$. latis, oblongis ad ellipticis, apice acutis vel breviter acuminatis, basi subrotundatis vel superiorum acutis vel cuneatis, margine plerumque acute dentatis, reticulatis, costa venisque primariis initio hirsutis, demum glabratis, venis primariis utrinque $8-12$, subtus prominentibus; inflorescentiis $\pm 25 \mathrm{~cm}$. longis, divaricate ramosis, hirsutulis, multifloris; floribus subsessilibus vel breviter pedicellatis, glabris; sepalis ciliolatis, subrotundis; petalis exterioribus late obovato-orbicularibus, circiter $1 \mathrm{~mm}$. longis, $1.5 \mathrm{~mm}$. latis, interioribus infra medium dorso filamentorum adnatis, utrimque in appendiculum brevem productis; staminodiis connatis; disco subannulari quam ovario paullo breviore, 5-lobato, lobis subulatis.

British New Guinea: Central Division, Mount Tafa, Brass 5050 (type), May-September, 1933, in the valley-forest, at about $2400 \mathrm{~m}$. alt. (small substage tree; leaves clustered at the ends of the branches; peduncle and pedicels reddish brown; flowers small, white and numerous). Northeastern New Guinea: Morobe District, without definite locality, Clemens 6262, January, 1937, at 2400-3200 m. alt.; Ogeramnang, Clemens 4465, 4828, December 2, 1936 and January 1, 1937, at \pm 2400 m. alt.; Goliteng Camp, Sarawaket Bush, Clemens 5288, February 1,1937 , at 2800-3200 m. alt.

This species suggests Meliosma nervosa Koord. \& Val. in the dentation and outline of the leaflets as shown in Koord. \& Val. Atlas Baumart. Java 2: $f .376 .1914$. It is not so glabrate a species and differs also in the subulate lobes of the disk and the shorter lobes of the inner petals (attached 
near the base of the filaments). In the angles between the midrib and the primary veins of the leaf is often a dense tuft of hairs.

Meliosma sarawakensis Ridley, Kew Bull. 1933: 193. 1933.

Meliosma grandifolia Lecomte, Bull. Soc. Bot. Fr. 54: 676. 1907, non Urban (1895).

Borneo: Sarawak, without definite locality, Native collector 106, 139, 2696.

Tentatively we assign these collections to this species. They are also close to $M$. latifolia Ridley. Unfortunately, we have no authentic specimens at hand for comparison, and the descriptions alone are not sufficiently precise to make clear the differences between these two species unless we accept Ridley's character "stamina 2, hirsuta" for M. latifolia . In the various Malaysian species we have scanned in an effort to locate our unnamed material we have not found any hirsute stamens, the tips of the appendages of the filaments may have a few very minute hairs, but in several of the species the ovary is somewhat hirsute or tomentose.

\section{Meliosma confertiflora sp. nov.}

Ramuli teretes, fusco-cinerei, novelli tomentoso-hirsuti; foliis imparipinnatis, alternis, plerumque 3-4-jugis; rachi $18-22 \mathrm{~cm}$. longa, initio tomentoso-hirsuta demum glabrata; petiolulis $5 \mathrm{~mm}$. longis; foliolis suboppositis vel inferioribus alternis, $8-15 \mathrm{~cm}$. longis, $3-4.5 \mathrm{~cm}$. latis, lanceolatis, acuminatis, basi inaequaliter obtusis, margine integris vel sparse subulato-dentatis, subtus reticulatis, costa venisque primariis undique \pm pubescentibus; venis primariis utrimque \pm 10 , subtus conspicuis; inflorescentiis ramosis, (in specimine typica) $9 \mathrm{~cm}$. longis, $4.5 \mathrm{~cm}$. latis, multifloris, rachi ramisque tomentoso-hirsutulis; floribus confertis, subsessilibus; sepalis ciliolatis, subrotundis; petalis exterioribus late rotundis vel obovatis, interioribus infra medium dorso filamentorum adnatis, utrimque in appendiculum brevem productis vel bi- tri-lobis; ovario parce pubescente.

British North Borneo: Mount Kinabalu, Dallas, Clemens 26961 (type), 26961bis, November 6 and 2, 1931, at about 900 m. alt.

This species, although closely approaching Meliosma sambucina (Jungh.) Miq. (= M. glauca Blume) in general habit, may be distinguished by the shorter petiolules, and the short and compact inflorescences. Although both specimens are in bud only, it does not seem as if the inflorescence could possibly grow to the size of that of $M$. sambucina (Jungh.) Miq. 
Meliosma rufo-pilosa Henderson, Gard. Bull. Straits Settl. 7: 96, t. 18. 1933.

British North Borneo: Mount Kinabalu, Tenompok, Clemens 28823, 28823 bis, 29909, March 14 and June 13, 1932, at about $1500 \mathrm{~m}$ alt.

These collections are a good match for an isotype of Meliosma rufopilosa Henderson. This rather distinct species has been previously reported only from Pahang.

Arnold Arboretum,

HARVARD UNIVERSITY. 


\section{$2 \mathrm{BHL}$ Biodiversity Heritage Library}

Merrill, Elmer D. and Perry, Lily M. 1939. "On Certain Malaysian Species of Meliosma Blume." Journal of the Arnold Arboretum 20(3), 356-360. https://doi.org/10.5962/p.325785.

View This Item Online: $\underline{\text { https://www.biodiversitylibrary.org/item/33596 }}$

DOI: https://doi.org/10.5962/p.325785

Permalink: https://www.biodiversitylibrary.org/partpdf/325785

\section{Holding Institution}

Missouri Botanical Garden, Peter H. Raven Library

\section{Sponsored by}

Missouri Botanical Garden

\section{Copyright \& Reuse}

Copyright Status: In copyright. Digitized with the permission of the rights holder.

Rights Holder: Arnold Arboretum of Harvard University

License: http://creativecommons.org/licenses/by-nc-sa/3.0/

Rights: https://biodiversitylibrary.org/permissions

This document was created from content at the Biodiversity Heritage Library, the world's largest open access digital library for biodiversity literature and archives. Visit BHL at https://www.biodiversitylibrary.org. 